\title{
Phytopathology
}

\section{Strawberries at the Crossroads: Management of Soilborne Diseases in California Without Methyl Bromide}

\author{
Gerald J. Holmes, ${ }^{1, \dagger}$ Seyed Mojtaba Mansouripour, ${ }^{1}$ and Shashika S. Hewavitharana ${ }^{1,2}$
}

${ }^{1}$ Strawberry Center, California Polytechnic State University, San Luis Obispo, CA 93407

${ }^{2}$ Horticulture and Crop Science Department, California Polytechnic State University, San Luis Obispo, CA 93407

Accepted for publication 18 February 2020.

\begin{abstract}
Strawberry production has historically been affected by soilborne diseases such as Verticillium wilt. This disease was a major limiting factor in strawberry production in California in the 1950s and was the main reason that preplant soil fumigation with methyl bromide (MB) was developed in the late 1950s. MB fumigation was so successful that over $90 \%$ of the commercial strawberry fruit production in California utilized this technique. However, MB was subsequently linked to ozone depletion, and its use was phased out in 2005 . The California strawberry industry was awarded exemption to the full phase-out until 2016, when all MB use in strawberry fruit production was prohibited. MB use continues in strawberry nurseries under an exemption to prevent spread of nematodes and diseases on planting stock. This review examines the impact of the MB phase-out on the California strawberry industry and evaluates the outlook for the industry in the absence of one of the most effective tools for managing soilborne diseases. New soilborne diseases have emerged, and historically important soilborne diseases have reemerged. Registration of new fumigants has been difficult and replacement of MB with a new and effective alternative is unlikely in the foreseeable future. Thus, crop losses due to soilborne diseases are likely to increase. Host plant resistance to soilborne diseases has become a top priority for strawberry breeding programs, and cultivars are increasingly selected for their resistance to soilborne diseases. The intelligent integration of a variety of management tactics is necessary to sustain strawberry production in California.
\end{abstract}

Keywords: disease control and pest management, fumigation, Fusarium oxysporum f. sp. fragariae, Fusarium wilt, Macrophomina charcoal rot, Macrophomina phaseolina, nematode, Phytophthora cactorum, Phytophthora root rot, Verticillium dahliae, Verticillium wilt

In the late 1950s, the fumigant methyl bromide (MB) was developed as a preplant soil treatment and successfully used to control soilborne diseases of strawberry. Chloropicrin, which was developed earlier, turned out to improve the efficacy and pest spectrum of MB when used in combination (Wilhelm et al. 1961). This fumigant combination was so effective that it was quickly and widely adopted throughout the California strawberry industry, saving the industry from near collapse from soilborne diseases such as Verticillium wilt. The impact of fumigation was so impressive that the famed naturalist photographer Ansel Adams captured and

${ }^{\dagger}$ Corresponding author: G. J. Holmes; gjholmes@calpoly.edu

The Cal Poly Strawberry Center was formed in 2014 as a partnership between the California Strawberry Commission and the California Polytechnic State University (Cal Poly) in San Luis Obispo. Its mission is to increase the sustainability of California's strawberry growers through research and education that is aligned with grower needs. Currently, the Strawberry Center has 12 staff addressing issues in the areas of plant pathology, entomology and automation/engineering. For more details go to https://strawberry.calpoly.edu/.

The author(s) declare no conflict of interest.

C 2020 The American Phytopathological Society named "strawberry fumigation" as one of the most important critical contributions of the first 100 years of the University of California system (Adams and Newhall 1967).

Over the next several decades, the California strawberry industry grew and evolved around fumigation as a cornerstone of the production system (Guthman 2019). Fumigation allowed for strawberries to be grown annually without rotation with other crops (Wilhelm and Paulus 1980). Breeding programs could focus more on yield and flavor than on resistance to soilborne diseases. In short, the production system was heavily dependent on fumigation for its continued success. Consequently, when $\mathrm{MB}$ was identified as an ozone depleter in the early 1990s and regulators moved to phase it out (Ristaino and Thomas 1997), the strawberry industry was deeply concerned with the prospect of growing strawberries without MB. This was followed by an intensive 25-year period of research to find effective alternatives to MB. The reader is referred to earlier reviews for details on this research (Duniway 2002; Martin 2003; Ristaino and Thomas 1997).

As of December 2016, MB is no longer used in strawberry fruit production in the United States (Gareau 2017). In this review, we report on the current status of soilborne diseases and their management in California strawberry fruit production, having recently lost $\mathrm{MB}$ as a tool for managing these diseases. 


\section{HISTORY OF CALIFORNIA STRAWBERRY PRODUCTION AND MB}

Benefits to the strawberry industry. The effects of preplant soil fumigation for California strawberry production were tested in the 1950s. In 1953, Wilhelm and Koch (1956) reported that application of chloropicrin to soil controlled Verticillium wilt, resulting in a twofold increase in yield. By the late 1950s, these researchers began testing mixtures of chloropicrin with $\mathrm{MB}$ and showed that MB not only improved disease control but also provided excellent weed control (Wilhelm and Paulus 1980). In the 1960s, this mixture became the standard because of its broader spectrum of activity and the chemicals' synergistic effect on the control of Verticillium dahliae in soil (Wilhelm 1966; Wilhelm and Paulus 1980; Wilhelm et al. 1961).

The new chloropicrin-MB mixture required tarping the soil surface with polyethylene film to slow the release of the fumigants from the soil into the atmosphere, thereby improving its efficacy. Within a few years, efficient application and tarping equipment were developed, and by 1965 , nearly $100 \%$ of the land used for strawberry plant production (i.e., nurseries) and fruit production was fumigated prior to each crop (Wilhelm and Paulus 1980).

These breakthroughs gave rise to a new era of strawberry production characterized by dramatically increased yields and greatly increased area under production. California strawberry hectares increased from 3,157 in 1966 to a peak of 16,518 in 2013. Industry-wide yields in California rose from an average of $14,347 \mathrm{~kg} / \mathrm{ha}$ in 1956 to $82,630 \mathrm{~kg} / \mathrm{ha}$ in 2018 , representing a $5.8-$ fold increase (Fig. 1) (U.S. Department of Agriculture-Agricultural Marketing Service 1950-2018). This increased yield was attributed to three main factors: higher-yielding cultivars producing fruit over a longer season (i.e., day neutrality), improved growing techniques, and control of soilborne diseases through fumigation with mixtures of $\mathrm{MB}$ and chloropicrin. Fumigation also results in plant growth promotion and higher yields even in the absence of soilborne diseases (Wilhelm and Paulus 1980).

MB phase-out. Concerns about the environmental impacts of soil fumigants began to mount in the 1980s (Farman et al. 1985). MB was implicated as contributing to the depletion of ozone $\left(\mathrm{O}_{3}\right)$ by reducing it to $\mathrm{O}_{2}$ (Yung et al. 1980). Concern over ozone depletion led to negotiations among countries that resulted in the 1987 drafting of the Montreal Protocol on 'Substances that Deplete the Ozone Layer' (United Nations Environment Program 1992). In 1990, MB was added to the list of substances that deplete the ozone layer. The international treaty stipulated that MB production between 1993 and 1998 would be held at the 1991 baseline consumption level of
$25,401,173 \mathrm{~kg} /$ year. By 1999 , a $25 \%$ reduction on this baseline level would be required. By 2001, a 50\% reduction, by 2003, a $70 \%$ reduction, and by 2005 , a $100 \%$ reduction would be required.

The Montreal Protocol allows for critical use exemptions (CUE), which were applied for in the United States by the U.S. Environmental Protection Agency (EPA) (Johnson et al. 2012). Between 2005 and 2016, CUEs were granted by the Parties of the Montreal Protocol to those commodities that could justify them. To justify a CUE, an industry must demonstrate that all technically and economically feasible steps have been taken to minimize the critical use, and that an appropriate effort is being made to evaluate, commercialize, and secure national regulatory approval of alternatives and substitutes (Rosskopf et al. 2005). CUEs for strawberry fruit ended in December 2016.

The second type of exemption under the Montreal Protocol is quarantine and preshipment (QPS), which authorizes MB use to control the introduction or spread of any new pest within the United States. This type of exemption is applied to imported commodities and domestic commodities growing in areas under quarantine for a regulated pest. $\mathrm{MB}$ continues to be used in strawberry nurseries under QPS exemption (as well as for a few other commodities such as fruit imported from Chile, exported oak logs, and other U.S. Department of Agriculture [USDA]-Animal Plant Health Inspection Service quarantines) to prevent the spread of soilborne nematodes and pathogens on nursery stock.

Resurgence and emergence of soilborne diseases. Verticillium wilt was the primary threat to strawberry fruit production in California and the primary target of early research on fumigation (Wilhelm and Paulus 1980). As MB phased out, two new diseases emerged in California and elsewhere: Macrophomina charcoal rot (caused by Macrophomina phaseolina) (Koike 2008) and Fusarium wilt (caused by Fusarium oxysporum f. sp. fragariae) (Koike et al. 2009). Macrophomina charcoal rot was reported in Florida (Mertely et al. 2005), Israel (Zveibil and Freeman 2005), Spain (Avilés et al. 2008), Argentina (Baino et al. 2011), Iran (Sharifi and Mahdavi 2012), Australia (Hutton et al. 2013), and Chile (Sánchez et al. 2013), and Fusarium wilt has been reported in Argentina, Australia, China, South Korea, Spain, and Japan (Koike et al. 2009).

\section{RESPONDING TO THE CHALLENGES}

In 2000, the USDA created the MB Transition Program to fund research on $\mathrm{MB}$ alternatives. This program has awarded $\$ 47.3$ million to 122 projects (https://cris.nifa.usda.gov). Considering all the MB-related grants along with other federal funding to find MB alternatives, this number would exceed $\$ 100$ million. Private

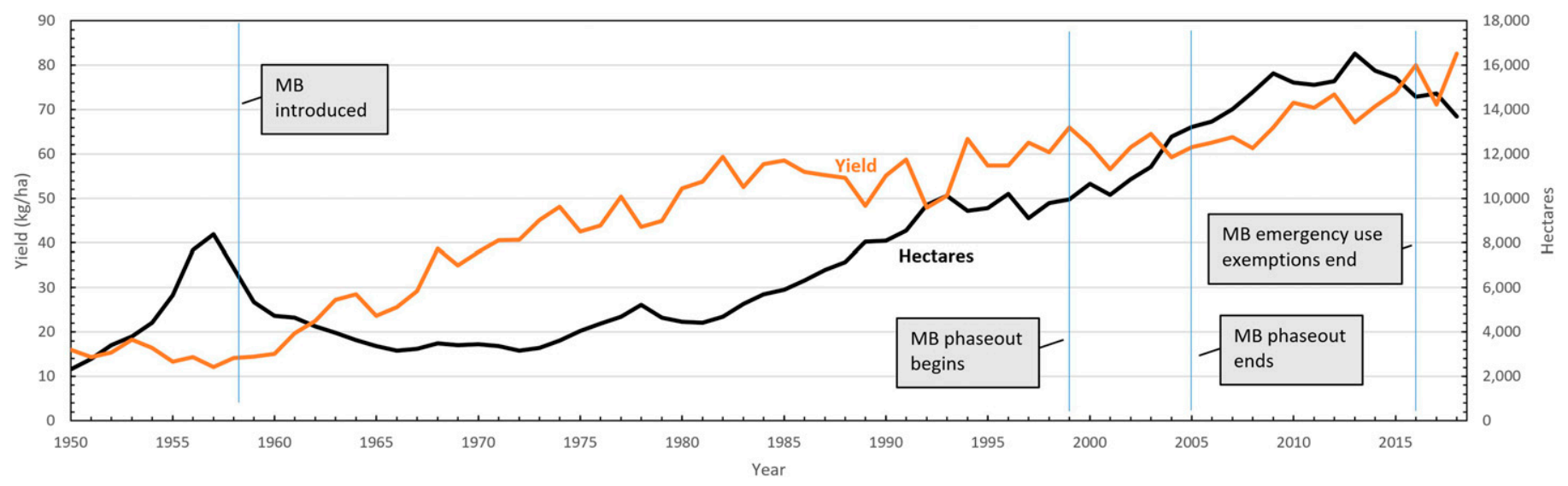

FIGURE 1

Hectares and yield of California strawberries from 1950 to 2018, including important strawberry industry milestones (California Strawberry Commission Acreage Survey 2020; U.S. Department of Agriculture-Agricultural Marketing Service 1950-2018). 
industry has spent an estimated $\$ 300$ million in the same pursuit. Along with the MB Transition Program, the Methyl Bromide Alternatives Outreach (MBAO) conference was organized to provide a forum for scientists and industry personnel to share research results in the area of $\mathrm{MB}$ alternatives. This conference has met annually since 1994 and is jointly sponsored by the Crop Protection Coalition, the U.S. EPA, and the USDA. Proceedings of this conference are available online (https://www.mbao.org/).

For details on research results on alternative fumigants prior to 2003, see Duniway (2002) and Martin (2003). Major chemical alternatives that have been evaluated are methyl isothiocyanate generators, allyl isothiocyanate (AITC), iodomethane, dimethyl disulfide (DMDS), and ethanedinitrile (EDN).

Chemical alternatives. Chloropicrin (trichloronitromethane) has been used as a soil fumigant since the 1920s and is still in use. It is typically formulated with other fumigants to increase the spectrum of activity as in the cases of MB, methyl iodide, 1,3dichloropropene (1,3-D), and AITC. Chloropicrin provides excellent control of some fungal and bacterial pathogens, but only provides fair efficacy against weed seeds and nematodes (Table 1) (Duniway 2002). Because of its strong odor and eye irritant properties, it is also used to alert users of poisoning. As MB use has declined, the use of chloropicrin has increased proportionally and is currently the most widely used fumigant in the California strawberry industry (Fig. 2).

Metam sodium (sodium N-methyl dithiocarbamate) and metam potassium (potassium $\mathrm{N}$-methyl dithiocarbamate) produce the bioactive chemical methyl isothiocyanate (MITC) in soil as they degrade. These MITC generators are available as stabilized aqueous solutions under several trade names (e.g., Vapam HL, K-Pam HL). MITC has broad-spectrum fumigant activity toward plant pathogenic nematodes, weeds, oomycetes, and fungi (Kreutzer 1963) (Table 1). Disadvantages of metam sodium are its limited mobility in soil and the requirement of mechanical placement or water infiltration for product delivery. Leaching out of the root zone, volatilization of irritant, and off-odors are potential issues with this fumigant. Both water caps and plastic films have been used to help address some of the problems (Duniway 2002).

Previous reports show that disease control efficacy and yield from metam sodium use have been inferior to that of the mixture of MB and chloropicrin (Shaw and Larson 1999; Trout and Ajwa 1999). Another disadvantage of MITC generators is that it reacts with chloropicrin and 1,3-D in aqueous solutions. This property prevents MITC generators from combined application with these fumigants (Trout and Ajwa 1999). One solution currently employed is to make sequential applications with several days of lag time. Larson (1998) reported that shank applications of chloropicrin followed 2 weeks later by drip application of metam sodium yielded near equivalent production of strawberry to that of an $\mathrm{MB}$ and chloropicrin combination. Due to the difficulty of attaining full activation of metam sodium by water infiltration, without causing phytotoxicity, it is typically utilized with another fumigant at lower rates (Duniway 2002).

Dazomet is still registered for nonbearing strawberry plants (i.e., nursery crops). In this capacity, it is used to augment weed and volunteer strawberry plant control. As a granular form of MITC, with trade names Basamid $\mathrm{G}$ and Temozad (AMVAC Chemical Corporation, Los Angeles, CA), it is utilized as a stand-alone treatment (Duniway 2002) or as a sequential application (Webb 1998) with other fumigants. Soil movement of the chemical has been extensively investigated (Gerstl et al. 1977; Smelt and Leistra 1974). Fennimore et al. (2008) studied preplant soil fumigation treatments of MB plus chloropicrin; iodomethane plus chloropicrin; a sequence of 1,3-D plus chloropicrin mixture and dazomet; a sequence of chloropicrin and dazomet; and a nonfumigated control at three California strawberry plant nurseries in both high and low elevations. They found that all alternative fumigant treatments controlled weeds to a comparable level as the MB-chloropicrin standard. Hand-weeding costs for all treatments were similar (Fennimore et al. 2008).

Allyl isothiocyanates (AITC) are considered to have the highest fungicidal toxicity on fungal pathogens compared with other isothiocyanates (allyl ITC>phenyl ITC>methyl ITC>ethyl ITC; Walker et al. 1937). AITC fumigant under the trade name Dominus (Isagro USA, Inc.) was federally registered in 2013 and available for use in Florida and other strawberry producing states. However, AITC is currently under review in California. Although the active ingredient is based on a plant-derived compound, it was not approved for certified organic production in the United States.

In a field trial conducted in Balm and Dover, Florida, efficacy of AITC in controlling $M$. phaseolina was compared with standard fumigants chloropicrin and 1,3-D with chloropicrin in tarped beds. Survival of the pathogen was significantly reduced in the AITC treatment in bags of inoculum buried at 7.6 and $20.3 \mathrm{~cm}$ deep in the

TABLE 1

General guide to the relative efficacy of soil fumigants against soilborne pests (modified from Anonymous 2009 and Rosskopf et al. 2016)

\begin{tabular}{|c|c|c|c|c|c|c|}
\hline Fumigant active ingredient & Fungi & Nematodes & Weeds & Insects & Mobility in soil & $\begin{array}{l}\text { In use as preplant soil } \\
\text { fumigant since }\end{array}$ \\
\hline Chloropicrin & $++++^{a}$ & ++ & ++ & ++ & ++ & 1927 \\
\hline Methyl bromide + chloropicrin & ++++ & ++++ & $+++/+$ & ++++ & ++++ & 1961 \\
\hline 1,3-Dichloropropene & + & ++++ & ++ & ++ & ++ & 1954 \\
\hline Metam potassium & +++ & +++ & +++ & ++ & + & 1973 \\
\hline Metam sodium & +++ & +++ & +++ & ++ & + & 1975 \\
\hline Allyl isothiocyanate & +++ & ++++ & ++ & ++ & + & 2013 \\
\hline Dimethyl disulfide & +++ & ++++ & ++ & ++ & ++++ & 2010 \\
\hline
\end{tabular}


center and $7.6 \mathrm{~cm}$ deep in the shoulder of the bed (Baggio et al. 2018). Another aspect of current research involves combining AITC with other treatments, such as steam (Hoffmann et al. 2017) and crop termination where AITC is applied via drip irrigation to kill a crop quickly and prevent inoculum production in crop residue (Chellemi et al. 2016).

Methyl iodide (iodomethane) has efficacy similar to that of MB (Table 1), but it is not an ozone-depleting substance. Its chemical properties allowed for direct substitution with MB into existing preplant fumigation equipment. Researchers at the University of California-Riverside patented the use of methyl iodide as a soil fumigant and then transferred the license to Arysta LifeScience. Concerns over methyl iodide's mammalian toxicity (Anonymous 2012) sparked opposition to its registration. The EPA registered methyl iodide in 2008, but it encountered legal challenges to its registration in California leading Arysta to eventually withdraw the product from the market in 2012 citing market disruption and economic limitations as the basis (Guthman 2019).

Dimethyl disulfide (DMDS) (Paladin) is an MB alternative fumigant that does not deplete ozone. Arkema and Cerexagri developed DMDS in the United States, Europe, and Mediterranean countries. DMDS alone or in combination with chloropicrin has shown efficacy toward controlling nematodes and soilborne diseases in both France and Italy (Heller et al. 2009). DMDS has a very strong odor described as pungent garlic, propane, or decaying fish. It was registered in the United States in 2010. In 2015, Arkema voluntarily withdrew their application for registration of Paladin in California, perhaps due to the risk its pungent odor presents in a more urbanized environment.

Ethanedinitrile (EDN) was first approved as a preplant soil fumigant for both strawberry plant and strawberry fruit production fields in Australia in 2018. It has not been registered in the United States. An in vitro study generated EDN dose-response curves against pathogenic fungi, parasitic nematodes, and weeds. The lethal concentration at which $90 \%$ of the pathogen propagules are expected die $\left(\mathrm{LC}_{90}\right)$ for $F$. oxysporum f. sp. fragariae, M. phaseolina, V. dahliae, and Pythium ultimum were 76, 180, 76, and $63 \mathrm{mg} / \mathrm{kg}$ of soil for California silt loam soil $(\mathrm{pH}=7.5)$ and 21 ,

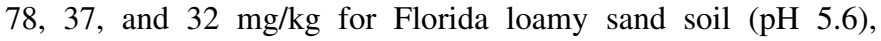
respectively (Ajwa et al. 2018). In strawberry field trials conducted at the Gulf Coast Research Education Center and Dover, Florida, EDN applied in water through drip tape at 336,448 , and $560 \mathrm{~kg} / \mathrm{ha}$ showed higher efficacy in controlling $M$. phaseolina compared with Paladin-Pic 21EC (dimethyl disulfide 78.1\%: chloropicrin 20.9\%) at $426 \mathrm{~kg} / \mathrm{ha}$ and Pic-Clor $60 \mathrm{EC}$ (1,3-D 39.0\%: chloropicrin 59.6\%) at $280 \mathrm{~kg} / \mathrm{ha}$ using cultivar Radiance (Thalavaisundaram et al. 2018). EDN along with Pic 100 (chloropicrin 99\%), using cultivar Sensation, significantly reduced $M$. phaseolina CFU compared with EDN or Pic-Clor 60 (Thalavaisundaram et al. 2018).

Low permeability films. Currently all strawberry production fields in California use raised beds covered with plastic mulch or film. Plastic film on raised beds serves several purposes, including optimum hydrothermal soil conditions, weed control (Fennimore et al. 2013) and as a barrier between soil and fruit. The former is important for early harvest and higher crop yield while the latter addresses fruit rot and food safety concerns. Today plastic mulch is used for both chemical-based (flat or bed application of fumigants) and cultural-based (e.g., soil solarization and anaerobic soil disinfestation) soilborne disease management practices. The advent of gas-impermeable plastic mulch was a highly significant milestone in fumigant application. Plastic film improves fumigant efficacy against soilborne diseases and limits fumigant emissions by minimizing fumigant escape from volatilization and thereby reduces the amount of fumigant to be applied (Qin et al. 2011). Several types of plastic, from a fumigant permeability aspect, have been studied and are in use including high density polyethylene (HDPE), virtually impermeable film (VIF), and totally impermeable film (TIF). TIF film was introduced in 2009 (Qin et al. 2013). The difference between traditional single-layer-high-density plastic (HDPE) and VIF or TIF is the presence of at least one

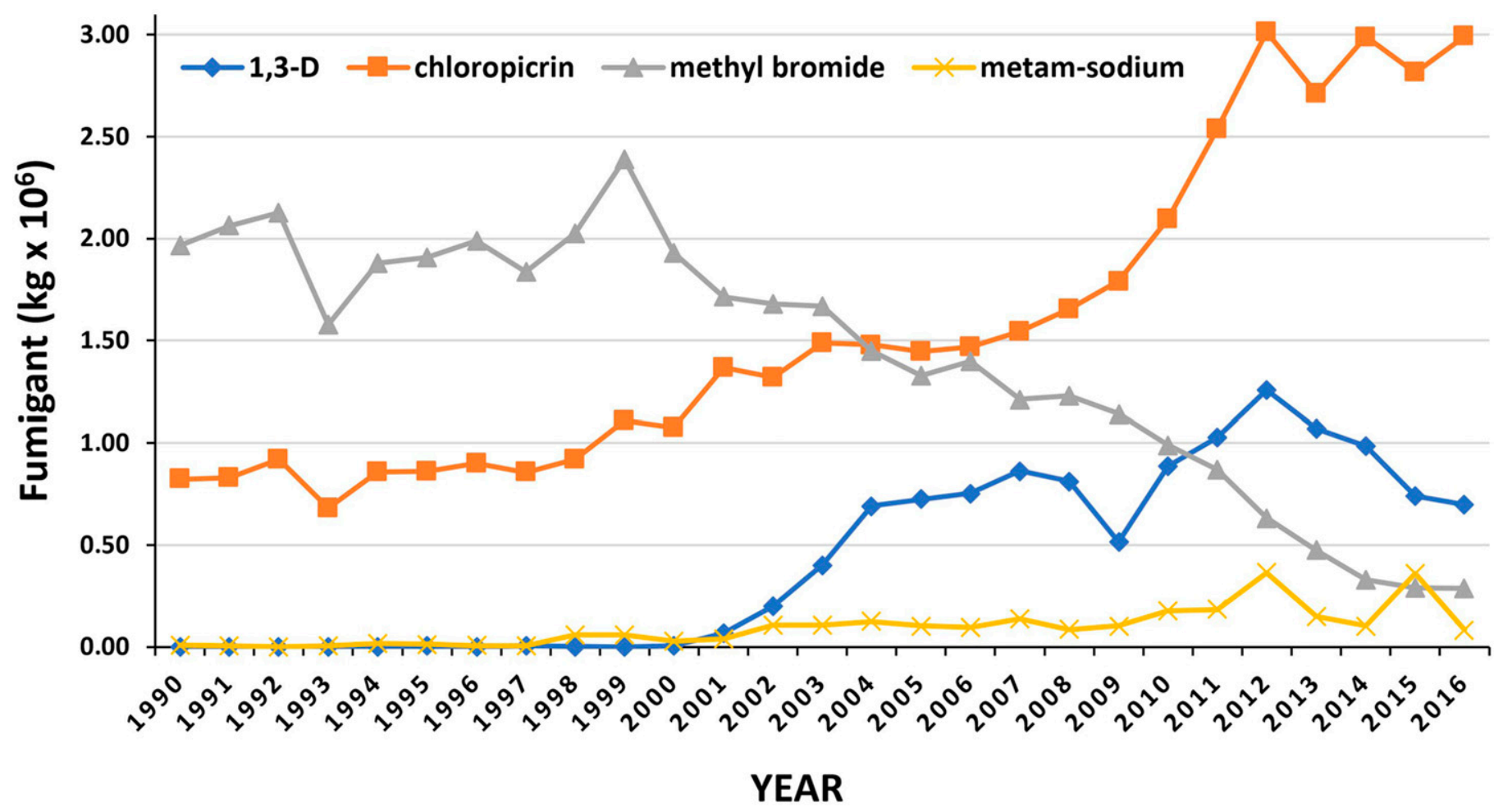

FIGURE 2

Changes in usage of four major fumigants (1,3-dichloropropene (1,3-D), chloropicrin, methyl bromide, and metam sodium) from 1990 to 2016 in California strawberry fields (California Department of Pesticide Regulation 2019). 
gas-impermeable layer (e.g., nylon or polyamines) between polyethylene layers (VIF), or the presence of five layers with two ethylene vinyl alcohol layers (TIF) (Fennimore and Ajwa 2011; Wang et al. 1997). TIF has been found to be better than VIF in retaining fumigant, weed suppression, soil pathogen control and improving strawberry yields (Fennimore and Ajwa 2011). These features have permitted the application of less fumigant while achieving similar efficacy compared with standard 1.25 -mil film and reduces regulatory restrictions (e.g., size of buffer zones) on fumigant use (Fennimore et al. 2013).

Nonfumigants applied through drip irrigation (fungicides and microbials). A variety of conventional and organic products have been evaluated as soil treatments applied through the drip irrigation system and as preplant transplant dips. Products evaluated include a vast array of both labeled and experimental products. These include registered conventional fungicides such as flutriafol (Rhyme), biologicals such as Trichoderma spp. (BioTam), mycorrhizae, Streptomyces-based products, and proprietary mixtures of single or multiple microbial species isolated from the strawberry rhizosphere. Several controlled environment and a few field studies have shown efficacy of various fungal and bacterial species including Bacillus spp., Serratia spp., and Trichoderma spp. against Fusarium wilt (Nam et al. 2009), Verticillium wilt and Phytophthora crown rot (Kurze et al. 2001), and Macrophomina crown rot (Pastrana et al. 2016). Most recently, research programs at the University of Florida and Cal Poly San Luis Obispo have evaluated more than 40 products over the course of 8 years without identifying any that deliver consistent performance (Blauer et al. 2018: Mertely et al. 2018). California strawberry growers experience a continuous stream of marketing and sales efforts to use these products without much knowledge or information on their mode of action and efficacy. Currently, none of these products has gained widespread use. Mazzola and Freilich (2017) discuss several reasons for the failure of biocontrol products, including inadequate colonization of the host rhizosphere.

Anaerobic soil disinfestation. Anaerobic soil disinfestation (ASD) was originally developed in Japan (Shinmura 2000) and in the Netherlands (Blok et al. 2000) independently. The ASD process involves generation of anaerobic conditions and disinfestation but not sterilization of soil (Butler et al. 2012). The three main steps of ASD are incorporation of an easily degradable carbon source into soil, irrigation of soil to fill the pore spaces, and covering with an oxygen-impermeable film to generate anaerobic conditions. The main carbon sources utilized for ASD in strawberry are rice bran, molasses, mustard seed meal, olive pomace, sugar beet vinasse, and composted poultry manure. The length of incubation has varied from 2 (Hewavitharana et al. 2014) to 15 weeks (Blok et al. 2000). Mechanisms of disease control have been extensively investigated; various toxic byproducts of anaerobic decomposition (Momma et al. 2006), soil microbial (Hewavitharana and Mazzola 2016) and metabolome (Hewavitharana et al. 2019) shifts, formation of specific metal ions such as $\mathrm{Mn}^{2+}$ and $\mathrm{Fe}^{2+}$ (Momma et al. 2011), and the anaerobic environment are the major effects. Still, no singularly identifiable mechanism has been found, and thus it may be a combination of effects that result in ASD performance.

Compatibility of ASD with use near urbanized areas where buffer zone restrictions would be most stringent for chemical fumigants is an advantage of the technique in California where strawberries are often grown near residential areas. Shennan et al. (2009) first evaluated ASD in California strawberries. They identified several challenges to adopting the technique on a commercial scale, including optimum incorporation of the carbon source into the soil and the addition of sufficient water to generate the anaerobic conditions required to induce disease suppression.

The main focal point of early ASD research in California was controlling $V$. dahliae. Using $20 \mathrm{t} / \mathrm{ha}$ of rice bran as the carbon source, preplant application of ASD with at least $75 \mathrm{~mm}$ of water in sandy-loam and clay-loam soil consistently reduced $V$. dahliae microsclerotia by 85 to $100 \%$ (Shennan et al. 2013, 2014). In a field trial conducted at three sites in CA using rice bran as the carbon source for ASD treatments (ASD-RB), ASD significantly improved strawberry yield of 'Albion' at two sites compared with the no treatment control. At one site, the effect of soil treatments on strawberry yield was assessed with or without preplant fertilizer. When ASD-RB and Pic-Clor 60 were applied with preplant fertilizer, both treatments performed equally. When the treatments were applied without preplant fertilizer, ASD-RB resulted in a higher yield. At the same site in this study, ASD-RB performed similar to MB/Pic 60 when the treatments were applied with no preplant fertilizer and ASD-RB performed better to MB/Pic 60 with preplant fertilizer (Mazzola et al. 2018). This indicates that ASD$\mathrm{RB}$ has fertilizer effects on top of its disinfestation properties. Pathogen suppression with ASD-RB at each site was superior to the no-treatment control at all three sites. Successful ASD treatments were consistently associated with altered composition of soil fungal and bacterial communities with induction of specific functional groups of microorganisms (Mazzola et al. 2018). Marketable strawberry yield in the ASD treatment was either equal to or higher than the Pic-Clor 60 treatment, according to Shennan et al. (2013). In trials conducted in Florida with composted broiler litter and blackstrap molasses as carbon sources, plant mortality due to M. phaseolina was significantly reduced ( $1 \%$ mortality) compared with the no-treatment control (3\% mortality) although complete elimination of plant death was not attained (Shennan et al. 2014).

Limits of ASD. Although success stories regarding soilborne disease suppression in strawberry using ASD have been reported, its adoption has been slow. This could be due to several factors. One of the main factors hindering adoption has been the cost for implementation. Cost for just tarping soil with VIF plastic was $€ 3,000$ ( $\$ 3,334.82$ ) per hectare in 2010 (Lamers et al. 2010). Cost for application of ASD with rice bran at $20 \mathrm{tha}^{-1}$ was $\sim \$ 6,000$ compared with $\$ 4,400$ for Pic-Clor 60) in 2014 (Muramoto et al. 2014). In certain instances, ASD has shown inferior disease control compared with grower standards. Disease control efficacy of ASD for Fusarium wilt has been lower compared with standard soil fumigation with PicClor 60 (Mazzola et al. 2018). Rice bran application in ASD treatment rates as high as $20 \mathrm{t} \mathrm{ha}^{-1}$ caused high nitrogen input into soil. However, studies have suggested the possibility of reducing preplant fertilizer in the ASD-treated fields to mitigate this issue (Muramoto et al. 2014). Unlike fumigant application, the ASD process requires multiple steps. Because the soil microbiome plays a significant role in the outcome and is affected by many environmental factors, such as soil $\mathrm{pH}$, temperature, soil texture, and incubation duration, the separation of all the optimum factors is a challenge. For instance, multiple studies have shown that it is critical to complete ASD application before the end of October to maintain soil temperature above $17^{\circ} \mathrm{C}$ at $15 \mathrm{~cm}$ depth in Watsonville and Santa Maria areas to attain successful disease control (Shennan et al. 2014). The technique has not been standardized for every unique situation. Efficacy of ASD has varied based on the application date due to soil temperature and the carbon source utilized. These factors have necessitated regional optimization of ASD (Mazzola et al. 2018).

One of the limitations for adoption of ASD in Florida has been the requirement for replacement of solarization plastic with dark plastic or application of opaque paint to reduce the temperature for optimum plant growth (Shennan et al. 2014). Another hindrance identified in vegetable systems in Florida is connected to composted broiler litter as the carbon source. Even though broiler litter has been composted, food safety concerns of Salmonella originating from it have lowered grower's adoption (Shennan et al. 2014). These obstacles are considered in ongoing research for developing substitute carbon sources and elimination of the need for plastic replacement (Shennan et al. 2014). 
Benefits of ASD. One of the main benefits of ASD is its compatibility with organic production. To date, organically compatible methods to control soilborne disease are very limited. Adoption of ASD in the California strawberry industry was approximately 162 ha in 2016 (Muramoto et al. 2016) and is currently approximately 800 ha (Kurt Jacobsen, personal communication). By 2014, ASD was commercially used only in California, although ASD was extensively studied in Florida as well (Shennan et al. 2014). In a large-scale organic trial conducted in Oxnard, CA, ASD using rice bran as the carbon source yielded double the fruit production relative to the grower standard and reduced plant death due to M. phaseolina by 10 to $13 \%$ (Muramoto et al. 2016).

Recently, growers have been modifying the purpose of ASD from one of disease suppression to fertilization. Rice bran is quickly converted to a significant amount of organic nitrogen. Because maintaining adequate nitrogen levels is a challenge for organic strawberry production, some growers are using rice bran as a mere fertilizer amendment and removing the irrigation and tarping steps necessary for proper ASD. There is evidence that rice bran itself can improve the strawberry yield and reduce $V$. dahliae in soil comparable to ASD with rice bran (Mazzola et al. 2018). However, application of rice bran without the optimum temperatures and proper anerobic conditions can induce proliferation of $F$. oxysporum f. sp. fragariae due to its ability to use rice bran as a substrate (Mazzola et al. 2018).

Sanitation. Disease control through sanitation begins by preventing introduction of soilborne pathogens into field soils. In California, use of disease-, nematode-, and pathogen-free transplants is paramount. Transplants are produced hundreds of miles away from fruit production fields. Nurseries in California produce nearly one billion strawberry plants annually (Subbarao et al. 2007). Strawberry nurseries can use MB under the QPS exemption because of the threat of spreading nematodes and pathogens on planting stock. Still, the system is not perfect, and recent outbreaks of diseases such Phytophthora root rot in strawberry fruit production fields have been associated with the use of infected strawberry transplants. Research is ongoing to improve disease detection and management in nurseries. It is the opinion of the authors that MB use should continue in nurseries until suitable alternatives are found. The benefits of MB fumigation in nurseries (i.e., disease-free plants) outweigh the costs of spreading soilborne pathogens and nematodes to other nurseries and fruit production fields in California and worldwide. A disease outbreak in a fruit production field is typically very site-specific whereas a disease outbreak in a nursery has the potential to be spread across many fields among several states and even internationally. The risk of spreading disease on plants is particularly important in California nurseries which

\section{FIGURE 3}

Table-top production system in Oxnard, California. Plants are grown in soilless media and precision-irrigated and -fertilized. The raised beds allow workers to pick in an upright position, while the soilless medium provides a pathogen-free environment for roots. supply plants to other nurseries nationally and internationally. Often international phytosanitary regulations require that imported strawberry plants be grown in soil fumigated with MB to reduce the likelihood of spreading nematodes and diseases. Furthermore, the amount of MB used in California nurseries represents approximately $10 \%$ of the total use prior to the phase-out.

Sanitation also includes preventing field-to-field movement of soil via farm equipment. Strawberries are intensively farmed, and many pieces of equipment frequently move through fields, making it difficult to sanitize equipment before transferring it between fields. Nonetheless, soil movement among fields should be minimized, and the benefits will be proportional to the reduction in soil movement, especially where fields with known soilborne pathogen infestations are involved.

Steam. Steam is an effective means of soil disinfestation and has been used for decades to control soilborne pests in greenhouse soils and potting mixes. Adapting steam treatment to production fields is challenging because of the requirement for a machine that can introduce steam into field soils at the proper temperature and duration. Despite these obstacles, several steam sterilization application rigs have been developed and are used for experimental purposes in golf courses, athletic turf, and floriculture industries, as well as strawberry fruit and nursery production fields. Effective treatment requires a temperature of $65^{\circ} \mathrm{C}$ for 20 to $30 \mathrm{~min}$, making speed of treatment a limiting factor (Fennimore and Goodhue 2016). Current soil steaming rigs can treat $0.25 \mathrm{ha} / 10 \mathrm{~h}$ at a cost of $\$ 12,000 /$ ha (Fennimore and Goodhue 2016), which currently is generally cost- and time-prohibitive. The rigs are also quite long, so they work best in large flat fields where there is enough space to turn. However, cost and time constraints could decrease over time as the technology improves. Steaming soils would require no buffer zones, has no restricted entry period, and no plant-back restrictions; these benefits could become more important as fumigants face increased regulations.

Steam treatment machinery is improving by mixing soil and coapplication with exothermic compounds. Steam generator technology has become more energy efficient, making rigs lighter and faster. Increased adoption will be driven by availability of fumigants, their efficacy and the regulations surrounding their use, as well as the cost, speed, and efficacy of steam treatment (Fennimore and Goodhue 2016; Hoffmann et al. 2017).

Substrate production systems. In parts of Europe, restrictions on soil fumigation combined with pathogen-infested soils and frequent rainfall have pushed strawberry farming to soilless systems (Lieten 2005; Neri et al. 2012). These range from plastic pots placed on top of raised field beds to table-top production in greenhouses or high plastic high tunnels (Fig. 3). Table-top production has several

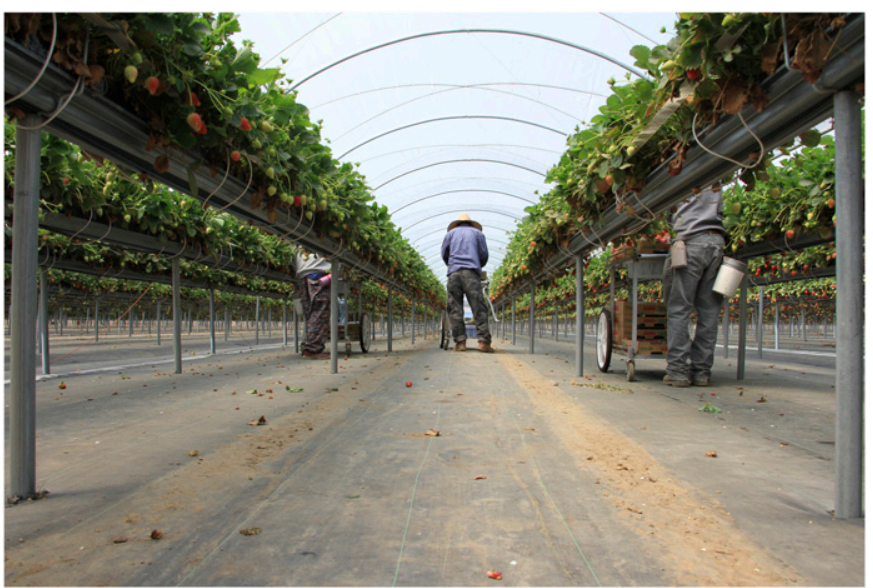


advantages: the potential elimination of soilborne pathogens and their diseases, ease of harvest, precise control of water and nutrition, and protection from rain and intense sunlight. However, this growing technique has not been widely adopted in California, and with the increased production costs, table-top production has been adopted on approximately 40 ha (Samtani et al. 2019). However, this method of production could expand to become more significant if soilborne diseases worsen and labor preferences favor it, but it would significantly increase the cost of production.

The California Strawberry Commission conducted five years of research on raised bed trough substrate production as a means of managing soilborne diseases. In this system, a standard field bed is made with a trough(s) running down the bed. The trough is lined with landscaping fabric, filled with substrate (peat or coconut coir) and the entire bed covered with standard plastic mulch. Strawberries are planted, grown and maintained just like conventional production, but with greater attention to water and nutrient needs (generally requiring a precision fertigation system). Legard and Thomas (2015) and Wang et al. (2016) concluded that although the raised bed trough production system was commercially possible for conventional production of strawberry fruit, it is not currently economically viable (increase cost of $\$ 8,000$ to $\$ 19,000 / \mathrm{ha}$ ), sufficiently free of risk of soilborne disease problems, or easy for California strawberry growers to adopt due the high level of technical expertise needed to successfully operate substrate production systems (Thomas et al. 2014).

Host plant resistance. Because $\mathrm{MB}$ was so effective at controlling soilborne diseases, breeding programs understandably focused on developing other traits (Guthman 2019). After the phase out of $\mathrm{MB}$, use of genetic resistance to control soilborne diseases became more attractive (Miles et al. 2018). The recently completed octoploid strawberry genome enables us to analyze disease resistance genetics in strawberries (Edger et al. 2019). Barbey et al. (2019) characterized R-gene collection in octoploid (Fragaria $\times$ ananassa 'Camarosa') and two diploid strawberries ( $F$. vesca and $F$. iinumae) using transcription profiling, $d \mathrm{~N} / d \mathrm{~S}$ analysis, expression quantitative trait loci (eQTL) analysis and resistance gene enrichment sequencing (RenSeq) analysis.

Resistance to Verticillium wilt in strawberry is quantitative and under complex control of multiple genes (Antanaviciute et al. 2015). This pathogen produces cell wall-degrading enzymes to penetrate its host. The presence of the chitinase gene (Pcht28) in strawberry causes resistance to $V$. dahliae because of the presence of chitin in the fungal cell wall. Chalavi et al. (2003) transferred this gene from Lycopersicon chilense to the strawberry cultivar Joliet in Canada and made it resistant to $V$. dahliae. Pérez-Jiménez et al. (2012) evaluated nine strawberry cultivars for resistance to $V$. dahliae in growth chambers and 10 cultivars for Phytophthora cactorum in the greenhouse. Results showed that, area under disease progress curve (AUDPC) of cultivar Sabrosa was not significantly different from the resistant control for both P. cactorum and $V$. dahliae. In another study, a biparental population of two octoploid strawberry parents-one resistant ('Red Gauntlet'), another susceptible ('Hapil') to V. dahliae-was screened in the field for three consecutive seasons. Eleven quantitative trait loci (QTL) for resistance to V. dahliae were detected across most linkage groups (LG) and then validated in the field for at least 1 year (Antanaviciute et al. 2015). These QTLs are valuable resources that could facilitate marker assisted selection to transfer Verticillium wilt resistance into new breeding lines. Maas et al. (1989) screened several cultivars for resistance to Verticillium sp. and found that Fragariae $\times$ ananassa clones 'MD-683', 'Aberdeen' and $F$. chiloensis clone 'Del Norte' had the highest levels of resistance to Verticillium wilt. Shaw et al. (1996) screened 41 University of California-Davis strawberry genotypes and 1,000 offspring from crosses among 23 of these 41 genotypes. Those plants were inoculated with a mixture of five $V$. dahliae isolates using a root dip method with $1 \times 10^{6}$ conidia/ml. Plant response was recorded six times throughout the season. At the end, 'Yolo' and 'Laguna' showed good resistance to Verticillium wilt. Holmes et al. (2017) showed a wide range of susceptibility among 90 strawberry cultivars and elite breeding lines using a naturally infested field site.

Several studies have focused on resistance in strawberry to M. phaseolina. In one study, eleven strawberry cultivars were inoculated using $M$. phaseolina-colonized oat seed in the greenhouse and using a sclerotial suspension in growth chambers to screen for resistance to this pathogen. Results showed that 'Festival', 'Amiga', and 'Naiad' were resistant by both methods (Sánchez et al. 2016). In another study, Koike et al. (2016) screened five strawberry cultivars against M. phaseolina; 'Seascape' showed resistance after 4 weeks but there were no significant differences among cultivars after 8 weeks and all of them were severely damaged by M. phaseolina. Avilés et al. (2008) conducted a study of two inoculation methods including a sclerotial suspension in pots and a fungus-colonized toothpick inserted into the crown to test 'Camarosa', 'Candonga', and 'Ventana'. Results showed that in the toothpick inoculation method there were no differences in severity among cultivars and all of them showed susceptibility. However, using the sclerotia suspension inoculation method, different susceptibilities to crown and root rot were observed (Avilés et al. 2008). In another study, in order to increase the level of resistance to M. phaseolina in strawberry plants, Hussein et al. (2016) applied artificial elicitors jasmonic acid (JA) and salicylic acid (SA) along with $M$. phaseolina at a concentration of $1 \times 10^{6}$ spores $/ \mathrm{ml}$ in strawberry cell culture. The results showed that, because of JA and SA application the transcription factor Fa WRKY 1, which is a homolog to At WRKY75 in Arabidopsis and plays an important role as a positive regulator of the defense system, was induced in strawberry plants. Later, the Fa WRKY 1-Camarosa gene, which is related to the defense response, was detected in elicited strawberry tissues using reverse transcription-polymerase chain reaction, which shows its defense-related function (Hussein et al. 2016). Holmes et al. (2017) screened 90 strawberry cultivars and elite breeding lines by inoculating plants shortly after transplanting and inducing water stress in late summer. This produced a wide range of responses, showing that host resistance can be used to partially control or delay this disease.

Resistance in strawberry to Fusarium wilt, caused by F. oxysporum f. sp. fragariae, has been studied extensively and a dominant resistance gene $(F w 1)$ identified (Pincot et al. 2018). Pincot et al. (2018) conducted a genome-wide association study on 565 strawberry accessions using 14,408 single nucleotide polymorphism (SNPs) over 2 years for resistance against $F$. oxysporum $\mathrm{f}$. sp. fragariae. Fourteen SNPs in linkage disequilibrium with $F w 1$ were mapped on chromosome 2 of diploid strawberry Fragaria vesca. Borrero et al. (2017) surveyed strawberry fields in Spain and collected diseased samples from 19 fields. They found 'Sabrosa' to be least susceptible to F. oxysporum f. sp. fragariae. Fang et al. (2012) found that 'Festival' is resistant to $F$. oxysporum $\mathrm{f}$. sp. fragariae. They found that resistance to $F$. oxysporum $\mathrm{f}$. $\mathrm{sp}$. fragariae is due to the impedance of pathogen growth and colonization on the plant surface and within host tissues. Fang et al. (2013) performed a transcriptome analysis of $F$. oxysporum $\mathrm{f}$. sp. fragariae-inoculated resistant and susceptible strawberries and showed that during $F$. oxysporum f. sp. fragariae infection in resistant cultivar Festival, the antioxidantrelated proteins have strong up-regulation, and down-regulation in susceptible cultivar Camarosa. These antioxidant-related enzymes detoxify reactive oxygen species and prevent cell damage because of oxidative activity (Fang et al. 2013). This study also showed upregulation of three isoforms of AdoMetS during infection with F. oxysporum f. sp. fragariae in resistant cultivars, which catalyzes the biosynthesis of S-Adenosyl methionine, the precursor molecule of ethylene in plants (Fang et al. 2013). Another up-regulated protein in resistant strawberries is allene oxide cyclase (AOC), which is an enzyme involved in the biosynthesis of JA. Ethylene and jasmonic 
acid are involved in systemic resistance, indicating that systemic resistance plays an important role during $F$. oxysporum $\mathrm{f}$. sp. fragariae infection in strawberry plants (Fang et al. 2013). Using a naturally infested field site, Holmes et al. (2017) showed that F. oxysporum f. sp. fragariae resistance performs very well under field conditions and is an effective means of controlling this disease.

Phytophthora cactorum (Leb. \& Cohn) Schroet. causes crown rot and leather rot of fruit. Cultivar screening done in Europe showed the importance of the plant's genetic background. Those cultivars that showed resistance had at least one resistant parent (Eikemo et al. 2003). The cultivar Nobel also showed tolerance to crown rot in Norway (Eikemo and Stensvand 2015). Mangandi et al. (2017) performed a QTL analysis that covered 21.0 Morgans (28 LG) using two multiparental population sets with Markov Chain Monte Carlo- based Bayesian analysis and FlexQTL software. A major QTL was found on LG 7D at position $63 \mathrm{cM}$. It was named FaRPc2 and explained $20 \%$ of the phenotypic variation. Davik et al. (2015) identified a major resistance gene to $P$. cactorum that is named RPC-1 (resistance to P. cactorum). This gene is located on LG 6 between S6-5569517 and S6-8871004 on the woodland strawberry (Fragaria vesca) genome. Nellist et al. (2019) found three major QTLs for resistance to $P$. cactorum (FaRPc6C, FaRPc6D, and FaRPc7D). Transcriptome analysis of inoculated strawberry roots of cultivar Hawaii 4 with known resistance to P. cactorum showed up-regulation of jasmonic acid, ethylene, and salicylic acid; several major allergen-like genes encoding PR-10 proteins; and expression of four nucleotide-binding site leucine-rich repeat proteins in the RPc-1 locus (Toljamo et al. 2016).

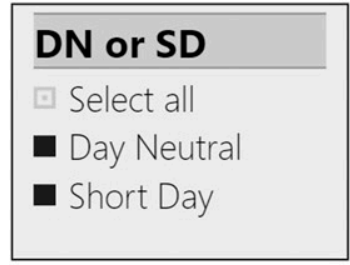

\begin{tabular}{|c|}
\hline Variety \\
\hline 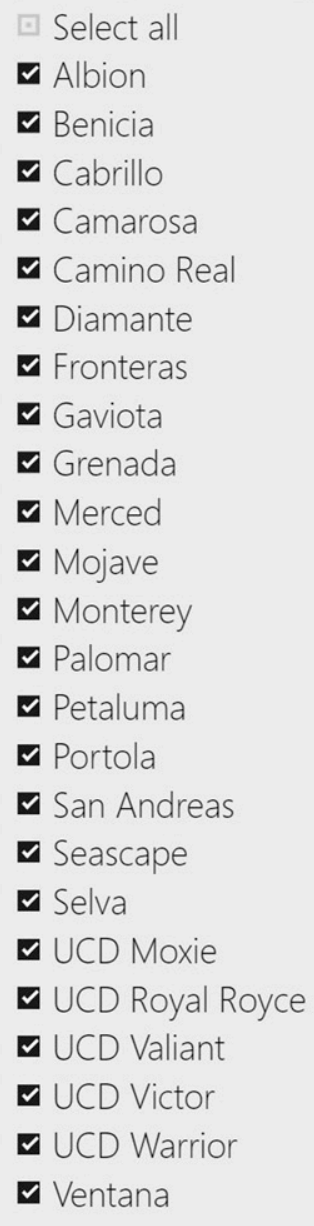 \\
\hline
\end{tabular}

\begin{tabular}{|c|c|c|}
\hline Legend Acronym & Legend & Resistance Numerical Category \\
\hline$R$ & Resistant & 1 \\
\hline MR & Moderate Resistance & 2 \\
\hline MS & Moderate Susceptibilty & 3 \\
\hline S & Susceptible & 4 \\
\hline
\end{tabular}

\begin{tabular}{|c|c|c|c|c|c|}
\hline Variety & Type & Macrophomina & Verticillium & Fusarium & Phytophthora \\
\hline UCD Warrior & SD & 2 & 3 & 1 & 2 \\
\hline Portola & DN & 4 & 2 & 1 & 2 \\
\hline UCD Victor & SD & 3 & 3 & 1 & 2 \\
\hline Camino Real & SD & 4 & 1 & 3 & 2 \\
\hline Diamante & DN & 3 & 3 & 1 & 3 \\
\hline Fronteras & SD & 3 & 3 & 1 & 3 \\
\hline San Andreas & $\mathrm{DN}$ & 4 & 2 & 1 & 3 \\
\hline UCD Moxie & DN & 4 & 2 & 1 & 3 \\
\hline Grenada & SD & 2 & 2 & 4 & 3 \\
\hline Petaluma & SD & 3 & 2 & 3 & 3 \\
\hline Ventana & SD & 4 & 3 & 1 & 3 \\
\hline Palomar & SD & 3 & 3 & 3 & 3 \\
\hline Selva & DN & 3 & 2 & 4 & 3 \\
\hline UCD Royal Royce & DN & 3 & 2 & 4 & 3 \\
\hline Albion & DN & 4 & 2 & 4 & 3 \\
\hline Cabrillo & $\mathrm{DN}$ & 4 & 2 & 4 & 3 \\
\hline Merced & SD & 4 & 3 & 4 & 2 \\
\hline UCD Valiant & DN & 4 & 2 & 4 & 3 \\
\hline Gaviota & SD & 4 & 3 & 4 & 3 \\
\hline Mojave & SD & 4 & 3 & 4 & 3 \\
\hline Monterey & DN & 4 & 3 & 4 & 3 \\
\hline Benicia & SD & 4 & 4 & 4 & 3 \\
\hline Camarosa & SD & 4 & 4 & 4 & 3 \\
\hline Seascape & DN & 4 & 4 & 4 & 3 \\
\hline
\end{tabular}

\section{FIGURE 4}

Screenshot of interactive web-based table showing the susceptibility of University of California-Davis strawberry varieties to soilborne diseases ( $1=$ resistant; 2 = moderate resistance; 3 = moderate susceptibility; and 4 = susceptible). Varieties are sorted in ascending order by the sum of resistance scores to four diseases: Macrophomina charcoal rot, Verticillium wilt, Fusarium wilt, and Phytophthora root rot (https://www. calstrawberry.com/en-us/Pest-Management/Breeding). 
Host plant resistance holds great potential for managing soilborne diseases. Tools have been developed to help growers select cultivars with specific disease resistances (Fig. 4). All major strawberry breeding programs have made soilborne disease resistance a top priority. Many advances have already been made and we expect much more progress soon.

\section{PROGRESS TOWARD SYSTEMS-BASED APPROACHES}

Crop rotation. Crop rotation is a classic method of soilborne disease management adopted in strawberry production. Crops rotated with strawberries in California vary by growing district. In the Oxnard region, diverse rotations, such as tomato, cilantro, and pepper are common. In the Santa Maria region, broccoli (Fig. 5), lettuce, cauliflower, and Brussels sprouts are common rotations; whereas in the Watsonville/Salinas region, common rotations include lettuce, leafy greens, spinach, and Brassicas. The lettuce-strawberry rotation has been the primary practice dominant in the Watsonville/ Salinas region (Chellemi et al. 2016). Strawberry nurseries use small grains and hay crops (wheat and triticale) in rotation with strawberries (D. Thomas, personal communication).

Integrated management of pathogens involves multiple practices that are intended to produce long-term effects on pathogen and disease reduction. One example of integrated management of Verticillium wilt of strawberry, especially in organic production systems, would be crop rotation to reduce the overwintering inoculum level in the soil (Njoroge et al. 2009). Although crop rotation was previously thought to not be applicable in strawberry due to the wide host range of pathogens such as Verticillium (Paulus, 1990), starting from the mid-1990s, rotation with broccoli has been shown to reduce Verticillium wilt in strawberry in conventional production (Subbarao et al. 2007) (Fig. 5). One study that illustrates this practice is Njoroge et al. (2009), which involved an organic and conventional production study comparing two successive crops of broccoli ('Marathon') or lettuce ('Salinas') prior to cultivars Aromas and Camarosa strawberry for infection with $V$. dahliae. They found that pathogen densities in broccoli rotation on conventional plots decreased by $44 \%$ in both years of assessment. In organic production, $V$. dahliae density was reduced $45 \%$ in the first year and $25 \%$ in the second year in broccoli rotation. However, no significant reduction of the pathogen densities was detected with a lettuce crop in either conventional or organic production (Njoroge et al. 2009). Lettuce is susceptible to Verticillium wilt, and $V$. dahliae isolates from lettuce are pathogenic to strawberries. Lettuce can tolerate a much higher soil density of Verticillium microsclerotia (>100 to $150 \mathrm{microsclerotia/g}$ of soil; Atallah et al. 2011), than susceptible strawberry cultivars, which requires only 2 microsclerotia/g soil to cause disease. Therefore,

FIGURE 5

Field of broccoli after harvest and prior to soil incorporation. Broccoli is one of the most common crop rotations with strawberry in California. During decomposition, broccoli produces allyl isothiocyanate. lettuce-strawberry rotations must be avoided in the absence of preplant soil fumigation due to the danger of increasing Verticillium wilt incidence.

Soil amendments. Soil amendments have been used in agriculture for millennia (Bailey and Lazarovits 2003). The primary goals behind utilization of soil amendments are to shift the soil microbiome toward one that is suppressive to soilborne pathogens, to alter soil structure, or to change chemical properties to optimum levels. Common soil amendments used in strawberry production include broccoli residue, chitin, rice bran, mustard seed meal, olive and grape pomace, almond hulls, compost, etc.

Broccoli residue is the dominant soil amendment in the Salinas Valley, where strawberry and lettuce rotation crops are common (Anonymous 2016a, b) (Fig. 5). It is primarily used to reduce Verticillium microsclerotial density, disease incidence, and severity (Njoroge et al. 2009; Xiao et al. 1998). Brassicaceae crops such as broccoli produce glucosinolates that generate AITC, which are toxic to fungal pathogens upon hydrolysis by the enzyme myrosinase (Mayton et al. 1996). Lignin in broccoli is assumed to promote proliferation of lignin-degrading microbes (Shetty et al. 2000), and some of these species can degrade fungal melanin (Butler and Day 1998). Therefore, lignin degraders can potentially reduce the viability of microsclerotia (Wheeler et al. 1976). However, broccoli rotation and incorporation of crop residues after removing the marketable crop itself has not provided sufficient control of Verticillium wilt in the following strawberry crop (Subbarao et al. 2007). Brassicaceae seed meal has also been studied as a soil amendment (Mazzola et al. 2016). In a controlled environment pot study, Brassica juncea seed meal was incorporated into soil and incubated for $24 \mathrm{~h}$ in gas-impermeable bags and then aerated for 8 weeks. M. phaseolina was artificially introduced into soil and immediately prior to planting bare root strawberry transplants of 'Camarosa'. The study focus was to exclude the contribution of AITC in observed disease suppression. Strawberry crown infection was significantly reduced by $B$. juncea treatment compared with the no-treatment control. It was speculated that as AITC production and emission is completed within 24 to $48 \mathrm{~h}$ after $B$. juncea incorporation, the observed disease suppression mechanism could be attributed to amplified Streptomyces spp. and total fungi in response to the treatment (Mazzola et al. 2016). However, in a scaled-up demonstration field trial conducted in an M. phaseolina-infested organic field in Oxnard, CA, where Brassica seed meal (B. juncea: Sinapis alba $=1: 1, \mathrm{wt} / \mathrm{wt}$ ) was compared to ASD with rice bran, ASD followed by Brassica seed meal, and a grower standard, Brassica seed meal alone failed to suppress M. phaseolina and fruit yield was inferior to that of ASD rice bran treatment (Muramoto et al. 2016). Fruit yield in ASD with rice bran followed by Brassica seed meal treatment was intermediate

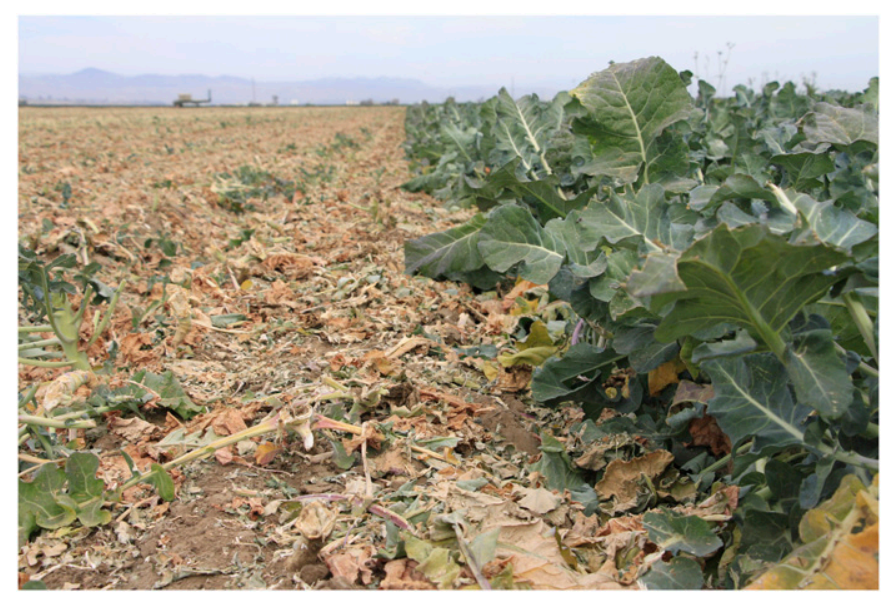


compared with ASD with rice bran alone and seed meal alone treatments (Muramoto et al. 2016).

Another soil amendment utilized for soilborne disease management is chitin derived from byproducts of the seafood industry, such as crab, lobster, and shrimp shells (Sharp 2013). Efficacy of chitin in controlling several soilborne diseases, including Fusarium yellows (Bell et al. 1998) and Verticillium wilt (Cretoiu et al. 2013), and plant parasitic nematodes (Rodriguez-Kabana et al. 1987) has been demonstrated. The soil bacterial community shifts to one that is abundant with Actinobacteria and the family Oxalobacteraceae was observed (Cretoiu et al. 2013), which can degrade chitin. Chitin can stimulate antagonists such as Bacillus spp. and Trichoderma harzianum (Sid Ahmed et al. 2003). Inderbitzin et al. (2018) conducted a controlled environment study to assess the effect of broccoli residue, chitin, broccoli residue plus chitin, or no amendment in Verticillium wilt-conducive soils from the Salinas Valley in California on soil bacterial community shifts, disease suppression, soil inoculum level reduction, plant growth, and soil chitinase activity. All amendments were effective in significantly reducing Verticillium wilt severity and pathogen inoculum and enhanced chitinase activity in the soil with high levels of Verticillium microsclerotia density. Inderbitzin et al. (2018) found significant impact from the treatments on the soil microbiome with significant correlations to the bacterial community structure. Known antagonist genera Pseudomonas spp. and Streptomyces spp. specifically correlated with the disease-related response variables. Amended soil harbored more antifungal antagonists than unamended soils did and composed up to $8.9 \%$ of all the bacterial sequences in the broccoli plus chitin treatment (Inderbitzin et al. 2018).

In California's Central Coast, application of compost every 1 to 2 years at 4.4 to $6.6 \mathrm{mt} / \mathrm{ha}$ in conventional production and 15.5 to 24.4 $\mathrm{mt} / \mathrm{ha}$ in organic production is a common practice (Lloyd et al. 2016). Application of compost has also been subjected to extensive research. Compost is known to improve soil properties, provide nutrients, and recycle waste (Millner et al. 2004). Furthermore, compost has shown the potential to improve plant growth and control plant pathogens by enrichment of the resident microbiome with beneficial microbial populations or amendment with biocontrol agents (De Ceuster and Hoitink 1999; Hoitink et al. 1997). In a combined greenhouse and field study conducted in Plymouth, North Carolina, strawberry cv. 'Chandler' transplants were grown in potting mix with either of two strains of Trichoderma species (T. hamatum (Bonord.) Bainier, strain T382 or T. harzianum Rifi, strain T22) or were untreated (Leandro et al. 2007). Transplants were then transferred to field plots treated with compost, compost amended with T. hamatum strain T382, Telone-C35 (1,3-D 63.4\%: chloropicrin $34.7 \%$ ), or no treatment. Biocontrol agent application produced improvement in plant dry weight and leaf area during the first year and had a positive impact on controlling root rot incidence in the second year. However, the biocontrol agents had no effect on those parameters after the plants were transplanted in soil. In comparison with Telone C-35 (63\% 1,3-D + 35\% chloropicrin), Leandro et al. (2007) found no benefit with compost or compost with the biocontrol agent on plant growth in the field.

A more recent study assessed the impact of four commercial composts - cow manure, spent mushroom substrate, yard trimmings, and vermicompost-on soil nutrient composition, soil microbiome and microbial activity, nutrient availability, and yield of 'Chandler' and/or 'Albion' in five field trials in the Central Valley (Sacramento County) (Lloyd et al. 2016). Manure and mushroom compost significantly increased soil electrical conductivity, and manure, yard trimmings, and mushroom compost changed the soil $\mathrm{pH}$ toward optimal levels for strawberries. Mushroom compost had the highest bacterial and fungal abundance. Mushroom compost and vermicompost had the highest microbial activity. These examples show that soil amendments can shift soil microbiomes toward conditions less conducive to strawberry soilborne patho- gens. High rates of applied compost can cause excessive available phosphorous and soluble salts (Millner et al. 2004). Strawberries are one of the most salt sensitive crops grown and will not tolerate high salts. Although, this issue could be mitigated with various methods such as the application of compost prior to planting to allow sufficient time for salts to leach out with rainfall or with another water source (Millner et al. 2004), it would lead to other problems such as leaching of salts which is now being regulated by the California waterboards (Central Coast Regional Water Quality Control Board 2017).

Crop termination. Crop termination is used to reduce inoculum build-up and dissemination due to tillage of infected strawberry plants after harvest when the field is prepared for the next season. Crop termination treatments are applied immediately after harvest to kill the existing crop and prevent additional inoculum formation (Chellemi et al. 2016). This method has an additional advantage of reducing worker exposure to pesticides in comparison with crop burndown herbicides (Khatri et al. 2018). Published literature on crop termination of strawberry is very limited. Khatri et al. (2018) used metam sodium as a crop-terminating chemistry against $M$. phaseolina in a field study conducted at an experimental research site in Balm, Florida. A series of high and low rates of metam sodium was tested with drip tape application. For all rates in the high-rate trial $(195,390,780,975$, and $1,170 \mathrm{~kg} / \mathrm{ha}),>60 \%$ crop mortality was observed at 7 days after fumigation, with $\mathrm{EC}_{50}$ of $127.6 \mathrm{~kg} / \mathrm{ha}$. All treatments resulted in $100 \%$ crop mortality at 14 days after fumigation. Except for the lowest rate, all other rates yielded 99 to $100 \%$ control of M. phaseolina inoculum placed at $8 \mathrm{~cm}$ depth in the strawberry bed. With respect to the lower rate series $(65,130,195,260$, and $325 \mathrm{~kg} / \mathrm{ha}), 45$ to $94 \%$ strawberry crop mortality was observed at 7 days. Except for the lowest rate all other rates yielded $>96 \%$ crop kill at 14 days after fumigation. Overall, $M$. phaseolina control was approximately $100 \%$ across the bed (Khatri et al. 2018).

Imperfections in individual approaches have driven the thinking toward a systems-based approach that evolved from the integrated pest management concept to a conglomeration of agricultural practices designed for naturally driven pest and disease suppression within the cropping system (Lewis et al. 1997). Chellemi et al. (2016) suggested a systems-based approach for managing soilborne plant pathogens using four pillars: (i) avoid introducing and disseminating pathogens into the cropping system, (ii) reduce the pathogen population using natural feedback mechanisms, (iii) introduce activities to the cropping system to promote diseasesuppressive soil microbiomes, and (iv) incorporate more integrated approaches rather than using pesticides. Chellemi et al. (2016) evaluated a case study using this strategy to manage Verticillium wilt in a strawberry and leafy green cropping system in California's central coast. The strategy, which had five components (use of clean planting material, soil disinfestation, beneficial crop rotation, organic amendments to transform the soil microbiome, and crop termination to prevent inoculum build-up and dissemination), successfully managed the disease and maintained the soil inoculum level below $1.0 \mathrm{~g}^{-1}$ (Chellemi et al. 2016). Additional long-term research conducted at multiple sites and dissemination of the results to growers are needed to enhance adoption of overarching methods such as a systems-based approach to mitigate soilborne diseases of strawberry.

\section{CONCLUSIONS AND PROSPECTS FOR THE FUTURE}

Although it is still too early to determine the full impact of the loss of MB, a few things are clear. The phase-out of MB has resulted in an increased use of other fumigants, especially chloropicrin and 1,3-D. Registration of new fumigants is very difficult, and none are as effective as $\mathrm{MB}$. Increasing regulatory pressure to reduce the use of fumigants in California is likely. A single treatment or tactic is 
unlikely to be as effective as MB. The number of soilborne fungal diseases affecting strawberries has increased to include Macrophomina crown rot and Fusarium wilt, while losses due to all soilborne diseases are increasing. Host plant resistance holds great promise for managing soilborne diseases and this has become a top priority for all strawberry breeding programs worldwide. Existing cultivars are increasingly selected for their resistance to soilborne diseases. The mechanisms conferring resistance and the levels of resistance vary by disease and genotype. Fusarium wilt has the simplest genetics with the greatest level of resistance; Macrophomina crown rot and Verticillium wilt have more complex genetics. New growing systems (e.g., table-top production) may offer solutions to soilborne diseases by eliminating soil while providing improved conditions for workers.

Strawberry production in California is indeed at a crossroads. Increased pressure from labor, regulations, or disease could tip the balance and lead to major shifts in growing practices and their costs. Currently, nurseries primarily use fumigation (including MB) to produce disease-free planting stock. One could argue the reasonableness of trading the minimal use of $\mathrm{MB}$ and its effects on the environment for the reduced risk of spreading nematodes and disease on planting stock worldwide. Fruit growers are selecting clean fields, practicing strict sanitation and crop rotation, employing host plant resistance, and using remaining fumigants to manage soilborne diseases. ASD is used on a limited scale against specific diseases in organic production systems while steam is effective but too slow and costly at present. We expect to see further improvement in host plant resistance and hope for treatments such as crop termination, crop debris removal or products with higher efficacy applied to soil or plants that will protect them from soilborne pathogens. If all else fails, substrate production systems remove soil and, therefore, most pathogens from the equation. Regardless, strawberries as an important specialty crop in California will likely survive. We will use an increasing variety of management tactics, which, if integrated intelligently, will allow strawberry production to continue indefinitely in California and beyond.

\section{ACKNOWLEDGMENTS}

We thank M. S. Stanghellini and D. E. Legard for their critical review of early drafts of this manuscript.

\section{LITERATURE CITED}

Adams, A., and Newhall, N. 1967. Fiat Lux. The University of California, McGraw-Hill, New York.

Ajwa, H., Thalavaisundaram, S., and Stanghellini, M. 2018. Dose response of weed seeds, nematodes, and pathogens to twelve rates of EDN. Pages 3.13.2 in: Proc. Annu. Int. Res. Conf. Methyl Bromide Altern. Emiss. Reduct. MBAO, Orlando, FL

Anonymous. 2009. General properties of fumigant formulations. Table 2-2 in: Pesticide Application Compendium 9: Field Fumigation. S. Cohen, T. A. Martin, and M. L. Flint, eds. UC-IPM Publication 9005. University of California Agriculture and Natural Resources.

Anonymous. 2012. Methyl bromide: Acute exposure guideline levels. In: Committee on Acute Exposure Guideline Levels; Committee on Toxicology; Board on Environmental Studies and Toxicology; Division on Earth and Life Studies; National Research Council. Acute Exposure Guideline Levels for Selected Airborne Chemicals: Volume 12. National Academies Press, Washington, D.C.

Anonymous. 2016a. Monterey County 2015 Crop Report. County of Monterey Agricultural Commissioner, Salinas, CA.

Anonymous. 2016b. Santa Cruz County 2014 Crop Report. Office of the Agricultural Commissioner, Watsonville, CA.

Antanaviciute, L., Šurbanovski, N., Harrison, N., McLeary, K. J., Simpson, D. W., Wilson, F., Sargent, D. J., and Harrison, R. J. 2015. Mapping QTL associated with Verticillium dahliae resistance in the cultivated strawberry (Fragaria $\times$ ananassa). Hortic. Res. 2:15009.

Atallah, Z. K., Hayes, R. J., and Subbarao, K. V. 2011. Fifteen years of Verticillium wilt of lettuce in America's salad bowl: A tale of immigration, subjugation, and abatement. Plant Dis. 95:784-792.
Avilés, M., Castillo, S., Borrero, C., Castillo, M. L., Zea-Bonilla, T., and Pérez-Jiménez, R. M. 2008. Response of strawberry cultivars: 'Camarosa', 'Candonga' and 'Ventana' to inoculation with isolates of Macrophomina phaseolina. Proc. VI International Strawberry Symposium 842:291-294.

Baggio, J. S., Chamorro, M., Cordova, L. G., Noling, J. W., Vallad, G. E., and Peres, N. A. 2018. Effect of formulations of allyl isothiocyanate on survival of Macrophomina phaseolina from strawberry. Plant Dis. 102:2212-2219.

Bailey, K. L., and Lazarovits, G. 2003. Suppressing soil-borne diseases with residue management and organic amendments. Soil Tillage Res. 72:169-180.

Baino, O. M., Salazar, S. M., Ramallo, A. C., and Kirschbaum, D. S. 2011. First report of Macrophomina phaseolina causing strawberry crown and root rot in northwestern Argentina. Plant Dis. 95:1477.

Barbey, C., Lee, S., Verma, S., Bird, K. A., Yocca, A. E., Edger, P. P., Knapp, S. J., Whitaker, V. M., and Folta, K. M. 2019. Disease resistance genetics and genomics in octoploid strawberry.G3-Genes Genom. Genet. 9: 3315-3332.

Bell, A. A., Hubbard, J. C., Liu, L., Davis, R. M., and Subbarao, K. V. 1998. Effects of chitin and chitosan on the incidence and severity if Fusarium yellows of celery. Plant Dis. 82:322-328.

Blauer, K. A., Gonzalez, O. A., and Holmes, G. J. 2018. Evaluation of preplant dip and soil drench treatments to control Verticillium wilt on fall planted strawberries, 2018. Plant Dis. Manage. Rep. 13:PF049.

Blok, W., Lamers, J., Termorshuizen, A., and Bollen, G. 2000. Control of soilborne plant pathogens by incorporating fresh organic amendments followed by tarping. Phytopathology 90:253-259.

Borrero, C., Bascón, J., Gallardo, M. Á., Orta, M. S., and Avilés, M. 2017. New foci of strawberry Fusarium wilt in Huelva (Spain) and susceptibility of the most commonly used cultivars. Sci. Hortic. (Amsterdam) 226:85-90.

Butler, D., Kokalis-Burelle, N., Muramoto, J., Shennan, C., McCollum, T., and Rosskopf, E. 2012. Impact of anaerobic soil disinfestation combined with soil solarization on plant-parasitic nematodes and introduced inoculum of soilborne plant pathogens in raised-bed vegetable production. Crop Prot. 39:33-40.

Butler, M. J., and Day, A. W. 1998. Fungal melanins: A review. Can. J. Microbiol. 44:1115-1136.

California Department of Pesticide Regulation. 2019. California pesticide information portal (CALPIP) application. https://calpip.cdpr.ca.gov/product.cfm

California Strawberry Commission. 2020. California Strawberry Acreage Survey. https://www.calstrawberry.com/en-us/Market-Data/Acreage-Survey

Central Coast Regional Water Quality Control Board. 2017. Water Quality Control Plan for the Central Coastal Basin. September 2017 Edition. California Environmental Protection Agency.

Chalavi, V., Tabaeizadeh, Z., and Thibodeau, P. 2003. Enhanced resistance to Verticillium dahliae in transgenic strawberry plants expressing a Lycopersicon chilense chitinase gene. J. Am. Soc. Hortic. Sci. 128:747-753.

Chellemi, D. O., Gamliel, A., Katan, J., and Subbarrao, K. V. 2016. Development and deployment of systems-based approaches for the management of soilborne plant pathogens. Phytopathology 106:216-225.

Cretoiu, M. S., Korthals, G. W., Visser, J. H., and van Elsas, J. D. 2013. Chitin amendment increases soil suppressiveness toward plant pathogens and modulates the actinobacterial and oxalobacteraceal communities in an experimental agricultural field. Appl. Environ. Microbiol. 79:5291-5301.

Davik, J., Eikemo, H., Brurberg, M. B., and Sargent, D. J. 2015. Mapping of the RPc-1 locus for Phytophthora cactorum resistance in Fragaria vesca. Mol. Breed. 35:211.

De Ceuster, T. C. C., and Hoitink, H. A. J. 1999. Prospects for composts and biocontrol agents as substitutes for methyl bromide in biological control of plant diseases. Compost Sci. Util. 7:6-15.

Duniway, J. M. 2002. Status of chemical alternatives to methyl bromide for pre-plant fumigation of soil. Phytopathology 92:1337-1343.

Edger, P. P., Poorten, T. J., VanBuren, R., Hardigan, M. A., Colle, M., McKain, M. R., Smith, R. D., Teresi, S. J., Nelson, A. D. L., Wai, C. M., Alger, E. I., Bird, K. A., Yocca, A. E., Pumplin, N., Ou, S., Ben-Zvi, G., Brodt, A., Baruch, K., Swale, T., Shiue, L., Acharya, C. B., Cole, G. S., Mower, J. P., Childs, K. L., Jiang, N., Lyons, E., Freeling, M., Puzey, J. R., and Knapp, S. J. 2019. Origin and evolution of the octoploid strawberry genome. Nat. Genet. 51:541-547.

Eikemo, H., and Stensvand, A. 2015. Resistance of strawberry genotypes to leather rot and crown rot caused by Phytophthora cactorum. Eur. J. Plant Pathol. 143:407-413.

Eikemo, H., Stensvand, A., Davik, J., and Tronsmo, A. M. 2003. Resistance to crown rot (Phytophthora cactorum) in strawberry cultivars and in offspring from crosses between cultivars differing in susceptibility to the disease. Ann. Appl. Biol. 142:83-89.

Fang, X., Jost, R., Finnegan, P. M., and Barbetti, M. J. 2013. Comparative proteome analysis of the strawberry-Fusarium oxysporum f. sp. fragariae pathosystem reveals early activation of defense responses as a crucial determinant of host resistance. J. Proteome Res. 12:1772-1788. 
Fang, X., Phillips, D., Verheyen, G., Li, H., Sivasithamparam, K., and Barbetti, M. J. 2012. Yields and resistance of strawberry cultivars to crown and root diseases in the field, and cultivar responses to pathogens under controlled environment conditions. Phytopathol. Mediterr. 51:69-84.

Farman, J. C., Gardiner, B. G., and Shanklin, J. D. 1985. Large losses of total ozone in Antarctica reveal seasonal $\mathrm{ClO}_{x} / \mathrm{NO}_{x}$ interaction. Science 315: 207-210.

Fennimore, S., Serohijos, R., Samtani, J., Ajwa, H., Subbarao, K., Martin, F., Daugovish, O., Legard, D., Browne, G., Muramoto, J., Shennan, C., and Klonsky, K. 2013. TIF film, substrates and nonfumigant soil disinfestation maintain fruit yields. Calif. Agric. 67:139-146.

Fennimore, S. A., and Ajwa, H. A. 2011. Totally impermeable film retains fumigants, allowing lower application rates in strawberry. Calif. Agric. 65: 211-215

Fennimore, S. A., and Goodhue, R. E. 2016. Soil disinfestation with steam: A review of economics, engineering, and soil pest control in California strawberry. Int. J. Fruit Sci. 16:71-83.

Fennimore, S. A., Haar, M. J., Goodhue, R. E., and Winterbottom, C. Q. 2008. Weed control in strawberry runner plant nurseries with methyl bromide alternative fumigants. HortScience 43:1495-1500.

Gareau, B. J. 2017. Sociology in global environmental governance? Neoliberalism, protectionism and the methyl bromide controversy in the Montreal protocol. Environments 4:73.

Gerstl, Z., Mingelgrin, U., and Yaron, B. 1977. Behavior of Vapam and ethylisothiocyanate in soils. Soil Sci. Soc. Am. J. 41:545-548.

Guthman, J. 2019. Wilted: Pathogens, Chemicals, and the Fragile Future of the Strawberry Industry. University of California Press, Oakland, CA.

Heller, J. J., Sunder, P. H., Charles, P., Pommier, J. J., and Fritsch, J. 2009. Dimethyl disulfide, a new alternative to existing fumigants on strawberries in France and Italy. Acta Hortic.: 953-956.

Hewavitharana, S., Rudell, D., and Mazzola, M. 2014. Carbon sourcedependent antifungal and nematicidal volatiles derived during anaerobic soil disinfestation. Eur. J. Plant Pathol. 140:39-52.

Hewavitharana, S. S., Klarer, E., Reed, A. J., Leisso, R., Poirier, B., Honaas, L., Rudell, D. R., and Mazzola, M. 2019. Temporal dynamics of the soil metabolome and microbiome during simulated anaerobic soil disinfestation. Front. Microbiol. 10:2365.

Hewavitharana, S. S., and Mazzola, M. 2016. Carbon source-dependent effects of anaerobic soil disinfestation on soil microbiome and suppression of Rhizoctonia solani AG-5 and Pratylenchus penetrans. Phytopathology 106: 1015-1028.

Hoffmann, M., Barbella, A., Miller, T., Broome, J., Martin, F., Koike, S., Rachuy, J., Greene, I., Dorn, N., Goodhue, R., and Fennimore, S. 2017. Weed and pathogen control with steam in California strawberry production. Proc. International Strawberry Symposium. Acta Hortic. 1156:593-602.

Hoitink, H. A. J., Stone, A. G., and Han, D. Y. 1997. Suppression of plant diseases by composts. HortScience 32:184-187.

Holmes, G., Ivors, K., Brantley, R., Winslow, J., and Gordon, T. 2017. Host plant resistance for management of Verticillium wilt, Fusarium wilt and Macrophomina crown rot in California strawberries. Pages 3-1 to 3-2 in: Proc. Annu. Int. Res. Conf. Methyl Bromide Altern. Emiss. Reduct. MBAO, San Diego, CA

Hussein, M. H. H., Abdel-Rahman, T. M. A., and Alwan, A. H. 2016. Defense response enhancement in strawberry via elicitors. 3 Biotech 6:130.

Hutton, D. G., Gomez, A. O., and Mattner, S. W. 2013. Macrophomina phaseolina and its association with strawberry crown rot in Australia. Int. J. Fruit Sci. 13:149-155.

Inderbitzin, P., Ward, J., Barbella, A., Solares, N., Izyumin, D., Burman, P., Chellemi, D. O., and Subbarao, K. V. 2018. Soil microbiomes associated with Verticillium wilt-suppressive broccoli and chitin amendments are enriched with potential biocontrol agents. Phytopathology 108:31-43.

Johnson, J. A., Walse, S. S., and Gerik, J. S. 2012. Status of alternatives for methyl bromide in the United States. Outlooks Pest Manag. 23:53-58.

Khatri, K., Baggio, J., Peres, N., and Boyd, N. 2018. Determination of optimum rate of metam potassium for crop kill weed and Macrophomina phaseolina control during strawberry crop termination. Pages 16.1-16.2 in: Proc. Annu. Int. Res. Conf. Methyl Bromide Altern. Emiss. Reduct. MBAO, Orlando, FL.

Koike, S. T. 2008. Crown rot of strawberry caused by Macrophomina phaseolina in California. Plant Dis. 92:1253.

Koike, S. T., Arias, R. S., Hogan, C. S., Martin, F. N., and Gordon, T. R. 2016. Status of Macrophomina phaseolina on strawberry in California and preliminary characterization of the pathogen. Int. J. Fruit Sci.: 148-159.

Koike, S. T., Kirkpatrick, S. C., and Gordon, T. R. 2009. Fusarium wilt of strawberry caused by Fusarium oxysporum in California. Plant Dis. 93:1077.

Kreutzer, W. A. 1963. Selective toxicity of chemicals to soil microorganisms. Annu. Rev. Phytopathol. 1:101-126.

Kurze, S., Bahl, H., Dahl, R., and Berg, G. 2001. Biological control of fungal strawberry diseases by Serratia plymuthica HRO-C48. Plant Dis. 85:529-534.
Lamers, J. G., Runia, W. T., Molendijk, L. P. G., and Bleeker, P. O. 2010. Perspectives of anaerobic soil disinfestation. Acta Hortic. 883:277-283.

Larson, K. D. 1998. Strawberry yield performance and response to ten preplant soil treatments. Pages 24-1-24.3 in: Proc. Annu. Int. Res. Conf. Methyl Bromide Altern. Emiss. Reduct. MBAO, Orlando, FL.

Leandro, L. F. S., Ferguson, L. M., and Louws, F. J. 2007. Strawberry growth and productivity in fumigated compared to compost-amended production systems. HortScience 42:227-231.

Legard, D. E., and Thomas, H. 2015. Development and demonstration of a Raised Bed Trough (RaBeT) substrate based system for producing strawberry fruit without fumigants. California Department of Pesticide Regulation Agreement Number 11-C0102.

Lewis, W. J., van Lenteren, J. C., Phatak, S. C., and Tumlinson, J. H., III. 1997. A total system approach to sustainable pest management. Proc. Natl. Acad. Sci. USA 94:12243-12248.

Lieten, F. 2005. Strawberry production in central Europe. Int. J. Fruit Sci. 5: 91-105.

Lloyd, M., Kluepfel, D., and Gordon, T. 2016. Evaluation of four commercial composts on strawberry plant productivity and soil characteristics in California. Int. J. Fruit Sci.: 84-107.

Maas, J. L., Galletta, G. J., and Draper, A. D. 1989. Resistance in strawberry to races of Phytophthora fragariae and to isolates of Verticillium from North America. Acta Hortic. 265:521-526.

Mangandi, J., Verma, S., Osorio, L., Peres, N. A., van de Weg, E., and Whitaker, V. M. 2017. Pedigree-based analysis in a multiparental population of octoploid strawberry reveals QTL alleles conferring resistance to Phytophthora cactorum. G3-Genes Genom. Genet. 7:1707-1719.

Martin, F. N. 2003. Development of alternative strategies for management of soilborne pathogens currently controlled with methyl bromide. Annu. Rev. Phytopathol. 41:325-350.

Mayton, H. S., Olivier, C., Vaughn, S. F., and Loria, R. 1996. Correlation of fungicidal activity of Brassica species with allyl isothiocyanate production in macerated leaf tissue. Phytopathology 86:267-271.

Mazzola, M., and Freilich, S. 2017. Prospects for biological soilborne disease control: Application of indigenous versus synthetic microbiomes. Phytopathology 107:256-263.

Mazzola, M., Hewavitharana, S. S., Strauss, S. L., Shennan, C., and Muramoto, J. 2016. Anaerobic soil disinfestation and Brassica seed meal amendment alter soil microbiology and system resistance. Int. J. Fruit Sci. 16:47-58.

Mazzola, M., Muramoto, J., and Shennan, C. 2018. Anaerobic disinfestation induced changes to the soil microbiome, disease incidence and strawberry fruit yields in California field trials. Appl. Soil Ecol. 127:74-86.

Mertely, J., Martin, R., and Peres, N. A. 2018. Evaluation of products for charcoal rot management in annual strawberry, 2016-2017. Plant Dis. Manag. Rep. 11:SMF030.

Mertely, J., Seijo, T., and Peres, N. 2005. First report of Macrophomina phaseolina causing a crown rot of strawberry in Florida. Plant Dis. 89:434.

Miles, T. D., Glass, B. W., Sysak, R. W., and Schilder, A. C. 2018. Post-plant strategies for management of black root rot-related decline of perennial strawberry fields. Crop Prot. 104:78-85.

Millner, P. D., Ringer, C. E., and Maas, J. L. 2004. Suppression of strawberry root disease with animal manure composts. Compost Sci. Util. 12:298-307.

Momma, N., Kobara, Y., and Momma, M. 2011. $\mathrm{Fe}^{2+}$ and $\mathrm{Mn}^{2+}$, potential agents to induce suppression of Fusarium oxysporum for biological soil disinfestation. J. Gen. Plant Pathol. 77:331-335.

Momma, N., Yamamoto, K., Simandi, P., and Shishido, M. 2006. Role of organic acids in the mechanisms of biological soil disinfestation (BSD). J. Gen. Plant Pathol. 72:247-252.

Muramoto, J., Shennan, C., Baird, G., Zavatta, M., Koike, S. T., Bolda, M. P., Daugovish, O., Dara, S. K., Klonsky, K., and Mazzola, M. 2014. Optimizing anaerobic soil disinfestation for California strawberries. Acta Hortic. 1044:215-220

Muramoto, J., Shennan, C., Zavatta, M., Baird, G., Toyama, L., and Mazzola, M. 2016. Effect of anaerobic soil disinfestation and mustard seed meal for control of charcoal rot in California strawberries. Int. J. Fruit Sci. 16:59-70.

Nam, M. H., Park, M. S., Kim, H. G., and Yoo, S. J. 2009. Biological control of strawberry Fusarium wilt caused by Fusarium oxysporum f. sp. fragariae using Bacillus velezensis BS87 and RK1 formulation. J. Microbiol. Biotechnol. 19:520-524.

Nellist, C. F., Vickerstaff, R., Sobczyk, M. K., Marina-Montes, C., Brain, P., Wilson, F. M., Simpson, D. W., Whitehouse, A. B., and Harrison, R. 2019. Quantitative trait loci controlling Phytophthora cactorum resistance in the cultivated octoploid strawberry (Fragaria $\times$ ananassa). Hortic. Res. 6:60.

Neri, D., Baruzzi, G., Massetani, F., and Faedi, W. 2012. Strawberry production in forced and protected culture in Europe as a response to climate change. Can. J. Plant Sci. 92:1021-1036.

Njoroge, S. M. C., Kabir, Z., Martin, F. N., Koike, S. T., and Subbarao, K. V. 2009. Comparison of crop rotation for Verticillium wilt management and 
effect on Pythium species in conventional and organic strawberry production. Plant Dis. 93:519-527.

Pastrana, A. M., Basallote-Ureba, M. J., Aguado, A., Akdi, K., and Capote, N. 2016. Biological control of strawberry soil-borne pathogens Macrophomina phaseolina and Fusarium solani, using Trichoderma asperellum and $\mathrm{Ba}$ cillus spp. Phytopathol. Mediterr. 55:109-120.

Paulus, A. L. 1990. Fungal diseases of strawberry. HortScience 25:885-889.

Pérez-Jiménez, R. M., De Cal, A., Melgarejo, P., Cubero, J., Soria, C., Zea-Bonilla, T., and Larena, I. 2012. Resistance of several strawberry cultivars against three different pathogens. Span. J. Agric. Res. 10:502-512.

Pincot, D. D., Poorten, T. J., Hardigan, M. A., Harshman, J. M., Acharya, C. B., Cole, G. S., Gordon, T. R., Stueven, M., Edger, P. P., and Knapp, S. J. 2018. Genome-wide association mapping uncovers $F w 1$, a dominant gene conferring resistance to Fusarium wilt in strawberry. G3-Genes Genom. Genet. 8:1817-1828.

Qin, R., Gao, S., Ajwa, H., Sullivan, D., Wang, D., and Hanson, B. D. 2011. Field evaluation of a new plastic film (Vapor Safe) to reduce fumigant emissions and improve distribution in soil. J. Environ. Qual. 40:1195-1203.

Qin, R., Gao, S., Thomas, J. E., Dickson, D. W., Ajwa, H., and Wang, D. 2013. Emissions from soil fumigation in two raised bed production systems tarped with low permeability films. Chemosphere 93:1379-1385.

Ristaino, J. B., and Thomas, W. 1997. Agriculture, methyl bromide, and the ozone hole: Can we fill the gaps? Plant Dis. 81:964-977.

Rodriguez-Kabana, R., Morgan-Jones, G., and Chet, I. 1987. Biological control of nematodes: Soil amendment and microbial antagonists. Plant Soil 100:237-247.

Rosskopf, E. N., Chellemi, D. O., Kokalis-Burelle, N., and Church, G. T. 2005. Alternatives to methyl bromide: A Florida perspective. Plant Health Prog. 6:19.

Rosskopf, E. N., Kokalis-Burelle, N., Fennimore, S. A., and Wilen, C. A. 2016. Soil/media disinfestation for management of florists' crops diseases. In: Handbook of Florists' Crops Disease, Handbook of Plant Disease Management. R. McGovern and W. Elmer, eds. Springer International Publishing, Cham.

Samtani, J. B., Rom, C. R., Friedrich, H., Fennimore, S. A., Finn, C. E., Petran, A., Wallace, R. W., Pritts, M. P., Fernandez, G., Chase, C. A., and Kubota, C. 2019. The status and future of the strawberry industry in the United States. HortTech. 29:11-24.

Sánchez, S., Gambardella, M., Henríquez, J. L., and Díaz, I. 2013. First report of crown rot of strawberry caused by Macrophomina phaseolina in Chile. Plant Dis. 97:996.

Sánchez, S., Henríquez, J. L., Urcola, L. A., Scott, A., and Gambardella, M. 2016. Susceptibility of strawberry cultivars to root and crown rot caused by Macrophomina phaseolina. J. Berry Res. 6:345-354.

Sharifi, K., and Mahdavi, M. 2012. First report of strawberry crown and root rot caused by Macrophomina phaseolina in Iran. Iranian J. Plant Pathol. 47: 379-387.

Sharp, R. G. 2013. A review of the applications of chitin and its derivatives in agriculture to modify plant-microbial interactions and improve crop yields. Agronomy (Basel) 3:757-793.

Shaw, D. V., Gubler, W. D., Larson, K. D., and Hansen, J. 1996. Genetic variation for field resistance to Verticillium dahliae evaluated using genotypes and segregating progenies of California strawberries. J. Am. Soc. Hortic. Sci. 121:625-628.

Shaw, D. V., and Larson, K. D. 1999. A meta-analysis of strawberry yield response to preplant soil fumigation with combinations of methyl bromidechloropicrin and four alternative systems. HortScience 34:839-845.

Shennan, C., Muramoto, J., Fennimore, S., Mazzola, M., and Lazarovits, G. 2013. Nonfumigant strategies for soilborne disease control in California strawberry production systems. California Strawberry Commission Annual Production Research Report 2011-2012:145-159.

Shennan, C., Muramoto, J., Koike, S., and Daugovish, O. 2009. Optimizing soil disinfestation for non-fumigated strawberry production in California. Pages 101.1-101.3 in: Proc. Annu. Int. Res. Conf. Methyl Bromide Altern. Emiss. Reduct. MBAO, San Diego, CA.

Shennan, C., Muramoto, J., Mazzola, M., Momma, N., Kobara, Y., Lamers, J., Rosskopf, E. N., Burelle, N. K., and Butler, D. 2014. Anaerobic soil disinfestation for soil borne disease control in strawberry and vegetable systems: Current knowledge and future directions. Acta Hortic. 1044:165-175.
Shetty, K. G., Subbarao, K. V., Huisman, O. C., and Hubbard, J. C. 2000. Mechanisms of broccoli-mediated Verticillium wilt reduction in cauliflower. Phytopathology 90:305-310.

Shinmura, A. 2000. Causal agent and control of root rot of Welsh onion. (In Japanese) PSJ Soilborne Dis. Work. Rep. 20:133-143.

Sid Ahmed, A., Ezziyyani, M., Sanchez, C. P., and Candela, M. E. 2003. Effect of chitin on biological control activity of Bacillus spp. and Trichoderma harzianum against root rot disease in pepper (Capsicum annum) plants. Eur. J. Plant Pathol. 109:633-637.

Smelt, J. H., and Leistra, M. 1974. Conversion of metam-sodium to methyl isothiocyanate and basic data on the behavior of methyl isothiocyanate in soil. Pestic. Sci. 5:401-407.

Subbarao, K. V., Kabir, Z., Martin, F. N., and Koike, S. T. 2007. Management of soilborne diseases in strawberry using vegetable rotations. Plant Dis. 91: 964-972.

Thalavaisundaram, S., McConville, K., and Trocha, A. 2018. Update on EDN for preplant application. Page 35.1 in: Proc. Annu. Int. Res. Conf. Methyl Bromide Altern. Emiss. Reduct. MBAO, Orlando, FL.

Thomas, H., Legard, D., and Rowe, D. 2014. A review of the final three seasons (2012, 2013 and 2014) of research and grower demonstrations of the raised bed trough $(\mathrm{RaBeT})$ substrate production system. California Strawberry Commission Annual Production Research Report 2014-2015. https://www.calstrawberry.com/en-us/Farm-Research/Annual-ResearchReports

Toljamo, A., Blande, D., Kärenlampi, S., and Kokko, H. 2016. Reprogramming of strawberry (Fragaria vesca) root transcriptome in response to Phytophthora cactorum. PLoS One 11:e0161078.

Trout, T., and Ajwa, H. 1999. Strawberry response to fumigants applied by drip irrigation systems. Proc. Annu. Int. Res. Conf. Methyl Bromide Altern. Emiss. Reduct. MBAO, San Diego, CA.

United Nations Environment Program. 1992. Montreal Protocol Assessment Supplement, Methyl Bromide: Its Science, Technology, and Economics. Synthesis Report of the Methyl Bromide Interim Scientific Assessment and Methyl Bromide Interim Technology and Economic Assessment.

U.S. Department of Agriculture-Agricultural Marketing Service. 1950-2018. California Strawberry Commission Acreage Survey. https://www.marketnews.usda.gov/mnp/fv-home

Walker, J. C., Morell, S., and Foster, H. H. 1937. Toxicity of mustard oils and related sulfur compounds to certain fungi. Am. J. Bot. 24:536-541.

Wang, D., Gabriel, M. Z., Legard, D., and Sjulin, T. 2016. Characteristics of growing media mixes and application for open-field production of strawberry (Fragaria ananassa). Sci. Hortic. (Amsterdam) 198:294-303.

Wang, D., Yates, S. R., Ernst, F. F., et al. 1997. Reducing methyl bromide emission with a high barrier plastic film and reduced dosage. Environ. Sci. Technol. 31:3686-3691.

Webb, R. 1998. Unique use of Basamid in combination with other fumigants in California strawberries. Page 25-1 in: Proc. Annu. Int. Res. Conf. Methyl Bromide Altern. Emiss. Reduct. MBAO, Orlando, FL.

Wheeler, M. H., Tolmsoff, W. J., and Meola, S. 1976. Ultrastructure of melanin formation in Verticillium dahliae with (+)-scytalone as a biosynthetic intermediate. Can. J. Microbiol. 22:702-711.

Wilhelm, S. 1966. Chemical treatments and inoculum potential of soil. Annu. Rev. Phytopathol. 4:53-78.

Wilhelm, S., and Koch, E. C. 1956. Verticillium wilt controlled. Calif. Agric. 10:3-14.

Wilhelm, S., and Paulus, A. O. 1980. How soil fumigation benefits the California strawberry industry. Plant Dis. 64:264-270.

Wilhelm, S. R., Storkan, R. C., and Sagen, J. E. 1961. Verticillium wilt of strawberry controlled by fumigation of soil with chloropicrin and chloropicrin-methyl bromide mixtures. Phytopathology 51:744-748.

Xiao, C. L., Subbarao, K. V., Schulbach, K. F., and Koike, S. T. 1998. Effects of crop rotation and irrigation on Verticillium dahliae microsclerotia in soil and wilt in cauliflower. Phytopathology 88:1046-1055.

Yung, Y. L., Pinto, J. P., Watson, R. T., and Sander, S. P. 1980. Atmospheric bromine and ozone perturbations in the lower stratosphere. J. Atmos. Sci. 37:339-353.

Zveibil, A., and Freeman, S. 2005. First report of crown and root rot in strawberry caused by Macrophomina phaseolina in Israel. Plant Dis. 89:1014. 